\title{
DNFSB Recommendation 94-1 Hanford Site Integrated Stabilization Management Plan
}

Date Published

September 1996

Prepared for the U.S. Department of Energy Assistant Secretary for Environmental Management

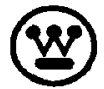




\section{RELEASE AUTHORIZATION}

Document Number: WHC-EP-0853, Rev. 4

Document Title: DNFSB Recommendation 94-1 Hanford Site Integrated Stabilization Management Plan

Release Date: $\quad 9 / 30 / 96$

This document was reviewed following the procedures described in WHC-CM-3-4 and is:

APPROVED FOR PUBLIC RELEASE

WHC Information Release Administration Specialist:

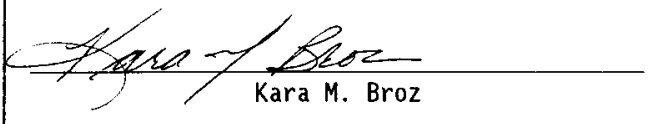




\section{DNFSB RECOMNENDATION 94-1 \\ HANFORD SITE INTEGRATED STABILIZATION \\ MANAGEMENT PLAN \\ VOLUME 3: PLUTONIUM VULNERABILITY CORRECTIVE ACTION PROGRAM}

\section{EXECUTIVE SUMMARY}

The Hanford Site Integrated Stabilization Management Plan (SISMP) was developed in support of the U.S. Department of Energy's (DOE) Defense Nuclear Facilities Safety Board (DNFSB) Recommendation 94-1 Integrated Program Plan (IPP). Volume 1 of the SISMP identifies the technical scope and costs associated with Hanford Site plans to resolve concerns identified in DNFSB Recommendation 94-1. Volume 2 of the SISMP provides the Resource Loaded Integrated Schedules for Spent Nuclear Fuel Project and Plutonium Finishing Plant activities identified in Volume 1 of the SISMP. Volume 3 of the SISMP identifies the 35 Plutonium Environmental, Safety, and Health Vulnerabilities. The vulnerabilities range from institutional problems to specific hardware problems. Many of the identified vulnerabilities will be corrected through the stabilization and packaging activities required by the DNFSB

Recommendation 94-1 Implementation Plan, the remainder will be corrected as a part of the plutonium handling facilities transition (deactivation) to the Environmental Restoration Program. 


\section{TABLE OF CONTENTS}

1.0 INTRODUCTION . . . . . . . . . . . . . . . . . . . 1

1.1 SCOPE

2.0 RL-1.0.1 COMPETING PRIORITIES FOR EXPERIENCED PERSONNEL . . . . . 6

3.0 RL-1.0.2 PENETRATION OF GLOVEBOX BARRIERS . . . . . . . . . 6

4.0 RL-1.0.3 ISOLATION AND LAYAWAY OF GLOVEBOXES . . . . . . . . . 6

4.1 Scope . . . . . . . . . . . . . . 6

4.2 Remediation objectives .............. 6

4.3 Remediation Process ................ 6

4.4 Schedule Objectives . . . . . . . . . . . . . . . 6

4.5 Assumptions . . . . . . . . . . . . . . . . . . . . 7

4.6 Issues and Problems ................. . . 7

4.7 Alternatives/Impacts ............... . . . 7

4.8 Technology Development . . . . . . . . . . . . 7

5.0 RL-1.0.4 POLYMER-BASED PANELS AND GLOVEBOXES WINDOWS ....... 7

5.1 Scope . . . . . . . . . . . . . 8

5.2 Remediation objectives ............... . . 8

5.3 Remediation Process . . . . . . . . . . . . . 8

5.4 Schedule Objectives . . . . . . . . . . . . . . . 8

5.5 Assumptions .................. . . . . 8

5.6 Issues and Problems . . . . . . . . . . . . . . . . 8

5.7 Alternatives/Impacts . . . . . . . . . . . . . 8

5.8 Technology Development . . . . . . . . . . . . . . . . 8

6.0 RL-1.0.5 PENETRATION OF CONTAMINATION CONTAINMENT/FIXATIVE . . . . g 9

6.1 Scope ................... 9

6.2 Remediation objectives ............... . . 9

6.3 Remediation Process ................. . . 9

6.4 Schedule objectives . . . . . . . . . . . . . . . 9

6.5 Assumptions . . . . . . . . . . . . ..... 10

6.6 Issues and Problems .................. 10

6.7 Alternatives/Impacts . . . . . . . . . . . . . 10

6.8 Technology Development ............... 11

7.0 RL-2.0.1 INSUFFICIENT KNOWLEDGE OF PACKAGING CONFIGURATION AND

NATURE OF MATERIAL IN BUILDING $324 \ldots \ldots \ldots$

8.0 RL-2.0.2 INSUFFICIENT KNOWLEDGE OF PACKAGING CONFIGURATION

AND NATURE OF MATERIAL IN BUILDING $325 \ldots \ldots \ldots . \ldots . \ldots 11$

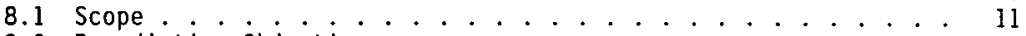

8.2 Remediation objectives ................ Il

8.3 Remediation Process .................. 11

8.4 Schedule objectives . . . . . . . . . . . . . . . . . 11

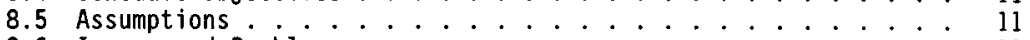

8.6 Issues and Problems . . . . . . . . . . . . . . . . . . . 11

8.7 Alternatives/Impacts . . . . . . . . . . . . . . 11

8.8 Technology Development .................... 12 
9.0 RL-2.0.3 INSUFFICIENT KNOWLEDGE OF PACKAGING CONFIGURATION

AND NATURE OF MATERIAL IN OTHER PNL BUILDINGS . . . . . . . . . . 12

10.0 RL-3.0.1 CRITICALITY ACCIDENT DURING DEACTIVATION OR

D\&D ACTIVITIES DUE TO ABNORMAL CONDITIONS . . . . . . . . . . . . 12

10.1 Scope . . . . . . . . . . . . . . . . . . . . 12

10.2 Remediation objectives . . . . . . . . . . . . . . . 12

10.3 Remediation Process . . . . . . . . . . . . . . . . . . 12

10.4 Schedule Objectives . . . . . . . . . . . . . . . 12

10.5 Assumptions ..................... . . 12

10.6 Issues and Problems . . . . . . . . . . . . . . . 13

10.7 Alternatives/Impacts . . . . . . . . . . . . . . . . . 13

10.8 Technology Development . . . . . . . . . . . . . . 13

$11.0 \mathrm{RL}-3.1 .2 .1 \quad 232-Z$ INCINERATOR CONTAMINATION RELEASE

DUE TO SEISMIC DESTRUCTION OF BUILDING . . . . . . . . . . . . . . . 13

12.0 RL-3.1.2.2 RELEASE OF PLUTONIUM HOLDUP IN EXHAUST DUCTSDOWNSTREAM

OF 234-5Z FINAL HEPA FILTERS VIA 291-Z STACK EXHAUST BLOWERS . . . . 13

12.1 Scope . . . . . . . . . . . . . . . . . . . . 13

12.2 Remediation Objectives . . . . . . . . . . . . . 13

12.3 Remediation Process . . . . . . . . . . . . . . . . 13

12.4 Schedule Objectives . . . . . . . . . . . . . . . . . . 14

12.5 Assumptions ................... . . 14

12.6 Issues and Problems . . . . . . . . . . . . . . . . . 14

12.7 Alternatives/Impacts . . . . . . . . . . . . . . . . . . . 14

12.8 Technology Development . . . . . . . . . . . . . . 14

13.0 RL-3.1.2.3 CONCRETE BLOCK WALL AND DOORS AT

SOUTH END OF PRF CANYON FAIL DBE ANALYSIS . . . . . . . . . . . . . 14

14.0 RL-3.1.3.1 HYDROGEN GENERATION IN SOLUTION STORAGE

CONTAINERS WHICH ARE NOT VENTED . . . . . . . . . . . . . . . 14

15.0 RL-3.1.3.2 PLUTONIUM STORED IN UNSTABLE FORMS . . . . . . . . . . . 14

15.1 Scope . . . . . . . . . . . . . . . . . . . 14

15.2 Remediation Objectives.................. . . 15

15.3 Remediation Process .................. . 15

15.4 Schedule Objectives . . . . . . . . . . . . . . . . 15

15.5 Assumptions ..................... . . . . . . 15

15.6 Issues and Problems ................. . . . 15

15.7 Alternatives/Impacts . . . . . . . . . . . . . . . . 15

15.8 Technology Development . . . . . . . . . . . . . 15

16.0 RL-3.1.3.3 DETERIORATION OF STORAGE CONTAINERS . . . . . . . . . 15

16.1 Scope ...................... . . . 15

16.2 Remediation Objectives................. . 16

16.3 Remediation Process .................... . 16

16.4 Schedule Objectives . . . . . . . . . . . . . . . . . 16

16.5 Assumptions ........................ . . . . 16

16.6 Issues and Problems ..................... 16

16.7 Alternatives/Impacts . . . . . . . . . . . . . . . . 16

16.8 Technology Development . . . . . . . . . . . . . . . . . . 16 
17.0 RL-3.1.3.4 INSUFFICIENT KNOWLEDGE OF PACKAGING

CONFIGURATION AND CHARACTERIZATION OF MATERIAL . . . . . . . . 16

17.1 Scope ....................... . . . 16

17.2 Remediation Objectives................ . 17

17.3 Remediation Process . . . . . . . . . . . . . . . . . 17

17.4 Schedule Objectives . . . . . . . . . . . . . . . 17

17.5 Assumptions ...................... . 17

17.6 Issues and Problems . . . . . . . . . . . . . . . 17

17.7 Alternatives/Impacts . . . . . . . . . . . . . . . . . 17

17.8 Technology Development ................ . . 17

18.0 RL-3.1.4.1 INJURY OR CONTAMINATION DURING PRF CANYON ENTRY . . . . 17

18.1 Scope ........................... 17

18.2 Remediation Objectives................... . . 18

18.3 Remediation Process . . . . . . . . . . . . . . . 18

18.4 Schedule objectives . . . . . . . . . . . . . . . . . . 18

18.5 Assumptions .................... 18

18.6 Issues and Problems ................... . . 18

18.7 Alternatives/Impacts . . . . . . . . . . . . . . 18

18.8 Technology Development . . . . . . . . . . . . . . 18

19.0 RL-3.1.4.2 REACTIVE CHEMICALS IN PFP GLOVEBOXES . . . . . . . . . . 18

20.0 RL-3.1.5.1 BREACH OF DRAIN LINES WITH HOLDUP IN PFP . . . . . . . . 18

20.1 Scope . . . . . . . . . . . . . . . . . 18

20.2 Remediation objectives.................. . . . 19

20.3 Remediation Process .................... . 19

20.4 Schedule Objectives . . . . . . . . . . . . . . . . 19

20.5 Assumptions . . . . . . . . . . . . . . . . . . . . . 19

20.6 Issues and Problems . . . . . . . . . . . . . . . . 19

20.7 Alternatives/Impacts . . . . . . . . . . . . . . . . 19

20.8 Technology Development . . . . . . . . . . . . . . 19

21.0 RL-3.1.5.2 HF CORROSION OF EXHAUST VENTILATION DUCTWORK AND

PRIMARY FILTERS SERVICING GLOVEBOX HC-9B AND HA-46 IN PFP . . . . . 19

21.1 Scope . . . . . . . . . . . . . . . . . . . . 19

21.2 Remediation Objectives.................. . 20

21.3 Remediation Process . . . . . . . . . . . . . . . . . 20

21.4 Schedule Objectives . . . . . . . . . . . . . . . 20

21.5 Assumptions ...................... . . . 20

21.6 Issues and Problems .................. . . . 20

21.7 Alternatives/Impacts . . . . . . . . . . . . . . . . . . . 20

21.8 Technology Development . . . . . . . . . . . . . . . . 20

22.0 RL-3.1.5.3 CORROSION OF DUCTWORK SERVICING LABORATORIES BY ACIDS . 20

22.1 Scope .................... 20

22.2 Remediation objectives ............... 21

22.3 Remediation Process . . . . . . . . . . . . . . . 21

22.4 Schedule Objectives . . . . . . . . . . . . . . . . 21

22.5 Assumptions . . . . . . . . . . . . . . . . . . 21

22.6 Issues and Problems .................. . . 21

22.7 Atternatives/Impacts . . . . . . . . . . . . . . . . . 21

22.8 Technology Development . . . . . . . . . . . . . . 21 
23.0 RL-3.1.5.4 WORKER EXPOSURE FROM EXHAUST VENTILATION

DUCTWORK AND PROCESS VACUUM SYSTEM ................. . 21

23.1 Scope . . . . . . . . . . . . . . . . . . 21

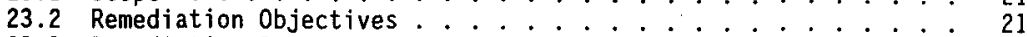

23.3 Remediation Process . . . . . . . . . . . . . . . 22

23.4 Schedule objectives . . . . . . . . . . . . . . . . . 22

23.5 Assumptions ......................... . . . . . . . . 22

23.6 Issues and Problems . . . . . . . . . . . . . . . . 22

23.7 Alternatives/ Jacts . . . . . . . . . . . . . . 22

23.8 Technology DE opment..................... 22

$24.0 \mathrm{RL}-3.1 .6 .1$ CONTAMINATION AND EXPOSURE FROM CLEANING 242-Z . . . . . 22

24.1 Scope .............................. 22

24.2 Remediation objectives...................... . . . 22

24.3 Remediation Process . . . . . . . . . . . . . . . . 22

24.4 Schedule Objectives . . . . . . . . . . . . . . . . . 22

24.5 Assumptions . . . . . . . . . . . . . . . . . . . . 22

24.6 Issues and Problems . . . . . . . . . . . . . . . . . . . . 23

24.7 Alternatives/Impacts . . . . . . . . . . . . . . . . . 23

24.8 Technology Development . . . . . . . . . . . . . . . 23

25.0 RL-3.2.1 PUREX PU RESIDUAL INVENTORY . . . . . . . . . . . . . . 23

25.1 Scope .......................... . . . . . . . . . . . . . . . . .

25.2 Remediation objectives . . . . . . . . . . . . . . . . 23

25.3 Remediation Process . . . . . . . . . . . . . . . . . 23

25.4 Schedule objectives . . . . . . . . . . . . . . . . . . . 23

25.5 Assumptions . . . . . . . . . . . . . . . . . . . . 23

25.6 Issues and Problems . . . . . . . . . . . . . . . . . . . 23

25.7 Alternatives/Impacts . . . . . . . . . . . . . . . . . 23

25.8 Technology Development . . . . . . . . . . . . . . . . 24

26.0 RL-3.2.2 RESIDUALS IN PUREX TUNNELS . . . . . . . . . . . . . . . . 24

26.1 Scope ...................... . . . . . 24

26.2 Remediation objectives....................... . . . . . 24

26.3 Remediation Process .................... . . . 24

26.4 Schedule objectives . . . . . . . . . . . . . . . . . . . 24

26.5 Assumptions ......................... . . . . . . . 24

26.6 Issues and Problems . . . . . . . . . . . . . . . . . . . . 24

26.7 Alternatives/Impacts . . . . . . . . . . . . . . . . . 24

26.8 Technology Development ... . . . . . . . . . . . . . 24

27.0 RL-3.2.3 RELEASE OF RESIDUAL DEEP BED FILTER

CONTAMINATION VIA THE PUREX MAIN STACK . . . . . . . . . . . . 24

27.1 Scope .. . . . . . . . . . . . . . . . . . . 25

27.2 Remediation Objectives................... . . . 25

27.3 Remediation Process . . . . . . . . . . . . . . . 25

27.4 Schedule objectives . . . . . . . . . . . . . . . . 25

27.5 Assumptions ....................... . . . . . . . 25

27.6 Issues and Problems . . . . . . . . . . . . . . . . . . . 25

27.7 Alternatives/Impacts . . . . . . . . . . . . . . . . . . . . 25

27.8 Technology Development . . . . . . . . . . . . . . . 25

28.0 RL-3.2.4 INADVERTENT BREACH OF GROSS PU CONTAMINATION 
BENEATH PAINT IN THE PUREX WHITE ROOM . . . . . . . . . . . . . 25

28.1 Scope . . . . . . . . . . . . . . . . . . . 25

28.2 Remediation Objectives................. . . 25

28.3 Remediation Process . . . . . . . . . . . . . . 26

28.4 Schedule Objectives . . . . . . . . . . . . . . . . . 26

28.5 Assumptions .................... 26

28.6 Issues and Problems . . . . . . . . . . . . . . . . . 26

28.7 Alternatives/Impacts . . . . . . . . . . . . . . . . 26

28.8 Technology Development . . . . . . . . . . . . . . 26

29.0 RL-3.3.1.1 CONTAMINATION SPREAD RESULTING FROM LOSS OF CONTROL

RESULTING FROM A ROOF FIRE AT RETIRED FACILITIES . . . . . . . . . . 26

29.1 Scope . . . . . . . . . . . . . . . . . 26

29.2 Remediation Objectives................. . 26

29.3 Remediation Process . . . . . . . . . . . . . . . . . 26

29.4 Schedule objectives . . . . . . . . . . . . . . . . . . 27

29.5 Assumptions . . . . . . . . . . . . . . . . . . . . 27

29.6 Issues and Problems . . . . . . . . . . . . . . . . . . 27

29.7 Alternatives/Impacts . . . . . . . . . . . . . . . . . 27

29.8 Technology Development . . . . . . . . . . . . . . . . . 27

30.0 RL-3.3.1.2 POTENTIAL LOSS OF CONTAINMENT INTEGRITY - RETIRED

FACILITIES: $222-\mathrm{B} \& \mathrm{~T}, 202-\mathrm{S}, 308,309,3706 . . . . . . . . . .27$

30.1 Scope ........................... 28

30.2 Remediation Objectives . . . . . . . . . . . . . . . . . 28

30.3 Remediation Process . . . . . . . . . . . . . . . . 28

30.4 Schedule Objectives . . . . . . . . . . . . . . . . 28

30.5 Assumptions . . . . . . . . . . . . . . . . . 28

30.6 Issues and Problems . . . . . . . . . . . . . . . . . . 28

30.7 Alternatives/Impacts . . . . . . . . . . . . . . 29

30.8 Technology Development . . . . . . . . . . . . . . . 29

31.0 RL-3.3.2.1 340 WASTE HANDL ING COMPLEX RELEASE TO ENVIRONMENT . . . 29

31.1 Scope ...................... . . . 29

31.2 Remediation Objectives.................. . . . . . 29

31.3 Remediation Process . . . . . . . . . . . . . . . 29

31.4 Schedule 0bjectives . . . . . . . . . . . . . . . . . 29

31.5 Assumptions . . . . . . . . . . . . . . . . . . . . . 29

31.6 Issues and Problems . . . . . . . . . . . . . . . 29

31.7 Alternatives/Impacts . . . . . . . . . . . . . . . . . . 29

31.8 Technology Development ................ . . 30

$32.0 \mathrm{RL}-3.3 .2 .2$ SAND FILTERS AT 221-B, 221-T, AND 202-S . . . . . . . 30

33.0 RL-3.3.2.3 Z-9 BUILDING FREQUENT CONTAMINATION OUTSIDE OF

ENGINEERED BARRIERS . . . . . . . . . . . . . . . . . . 30

33.1 Scope .. . . . . . . . . . . . . . . . . . . . . . . . . 30

33.2 Remediation Objectives................. . 30

33.3 Remediation Process ................... . . 30

33.4 Schedule Objectives ................. . . 30

33.5 Assumptions . . . . . . . . . . . . . . . . . . . 30

33.6 Issues and Problems . . . . . . . . . . . . . . . . 30

33.7 Alternatives/Impacts . . . . . . . . . . . . . . . 30 
33.8 Technology Development .............. . . 30

34.0 RL-3.3.2.4 RELEASE OF PLUTONIUM FROM 231-Z DUCT . . . . . . . . 31

34.1 Scope ..................... 31

34.2 Remediation objectives ............... 31

34.3 Remediation Process .................. 31

34.4 Schedule objectives ................ 31

34.5 Assumptions ....................... 31

34.6 Issues and Problems ................. . . 31

34.7 Alternatives/Impacts . . . . . . . . . . . . . 31

34.8 Technology Development . . . . . . . . . . . 31

35.0 RL-3.3.2.5 RESIDUAL PLUTONIUM IN 209-E ............ 31

35.1 Scope ...................... 31

35.2 Remediation objectives ................. 32

35.3 Remediation Process ................ 32

35.4 Schedule objectives ........................... 32

35.5 Assumptions ......................... 32

35.6 Issues and Problems . . . . . . . . . . . . . . . 32

35.7 Alternatives/Impacts .............. 32

35.8 Technology Development . . . . . . . . . . . . 32

36.0 RL-WGAT-1 CRITICALITY AND CONTAMINATION POTENTIAL IN SETTLING

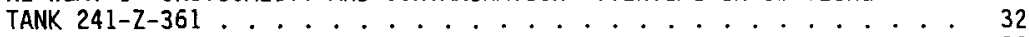

36.1 Scope . . . . . . . . . . . . . . 32

36.2 Remediation objectives ............... 32

36.3 Remediation Process . . . . . . . . . . . . 32

36.4 Schedule Objectives ................. 33

36.5 Assumptions . . . . . . . . . . . . . . . . . 33

36.6 Issues and Problems . . . . . . . . . . . . . . 33

36.7 Alternatives/Impacts .................... 33

36.8 Technology Development . . . . . . . . . . . . . 33

\section{LIST OF TABLES}

1. Hanford Plutonium ES\&H Vulnerabilities . . . . . . . . . . 3

2. Schedule Objectives for RL-1.0.3 . . . . . . . . . . . . 7

3. Schedule 0bjectives for RL-1.0.4 .............. . . 8

4. Schedule objectives for RL-1.0.5 . . . . . . . . . . . . 10

5. Plutonium Vulnerability RL-3.3.1.1 Status . . . . . . . . . . 27

6. Plutonium Vulnerability RL-3.3.1.2 Status . . . . . . . . . 28 
WHC-EP-0853 REV. 4

This page intentionally left blank 


\subsection{INTRODUCTION}

The Hanford Site Self Assessment of Plutonium Environmental Safety and Health (ES\&H) Vulnerabilities was conducted in accordance with the U.S. Department of Energy (DOE) Secretary's directive of February of 1994. The implementation plans to carry out this directive are contained in the Project Plan and the Assessment Plan. For this assessment, vulnerabilities are defined as "conditions or weaknesses that may lead to unnecessary or increased radiation exposure of the workers, release of radioactive materials to the environment, or radiation exposure of the public."

The Project Plan calls for all isotopes and forms of plutonium separated from reactor fuels to be included in the assessment scope with certain defined exceptions. Details are contained in the Project Plan; however, the principal exceptions explained in Figure 2 follow:

- Intact nuclear weapons

- Nuclear explosives assemblies

- Plutonium dispersed in nuclear device testing

- Plutonium in high-level, low-level, and transuranic (TRU) wastes

- Plutonium in facilities that are in the Decontamination and Decommission (D\&D) Program

- Irradiated fuel

The purpose of the Assessment was to evaluate environmental, safety, and nealth vulnerabilities from plutonium operations and storage activities. Acts of sabotage or diversion of plutonium which obviously may have ES\&H implications are excluded from this study because separate DOE programs evaluate those issues on a continuing basis. Security and safeguards activities which may have negative impacts on safety are included in the evaluation.

The Hanford Site is a $1,450-\mathrm{km}^{2}\left(560-\mathrm{mi}^{2}\right)$ tract of semiarid land located within the Columbia River Basin in southeastern Washington State. Figure 1 is a Site Map.

Since the early $1940^{\prime} \mathrm{s}$, the Hanford Site has been engaged primarily in weapons material production and nuclear energy research and development. Since the late 1980's, the mission of the Hanford Site has changed to one of restoration and cleanup. One legacy of earlier missions is several facilities that contain quantities of plutonium. These plutonium quantities potentially present Environmental, Safety, and Health vulnerabilities for the Site.

In order to effectively evaluate the vulnerabilities, this Hanford Site Self Assessment of Plutonium Environmental Safety and Health Vulnerabilities was conducted. More than 500 Hanford Site buildings were evaluated for inclusion in this Assessment. All buildings that have ever handled plutonium were 
identified and designated as in-scope or out-of-scope of this assessment. Burial grounds, tank farms, and liquid waste disposal sites (e.g., pond, cribs, ditches, and reverse wells [french drains]), were defined as out-ofscope by the U.S. Department of Energy-Headquarters (DOE-HQ) Assessment leaders. Facilities that have been turned over to the Decontamination and Decommissioning Program were also excluded from the scope. Plutonium contained in irradiated fuel (e.g., the Fast Flux Test Facility and K Basins) is covered in the Spent Fuel Vulnerability Assessment.

There was no discovery of previously unknown conditions or circumstances; however, the review has provided the opportunity to refocus attention on some matters that need thoughtful consideration and response. There were no catastrophic consequences identified.

A total of 35 vulnerabilities were identified at Hanford (including PNNL). These vulnerabilities are mostly attributable to aging of facilities; facility operations being terminated prior to removal of residual plutonium; some lack of characterization of material and container configuration of the plutonium stored in vaults, lack of direction and planning for long-term storage/disposition of plutonium; loss of "corporate memory"; and increasing competition for available personnel resources. Additionally, reduction of funding is a potential threat to the maintenance of the required safety infrastructure.

The potential for loss of contamination control exists in several retired facilities because many of the former plutonium laboratories have been turned into office buildings. Contamination still exists under paint and in the ducts. The inadvertent penetration of a containment or confinement barrier could result in contamination of personnel or environs.

The plans to correct the 35 identified vulnerabilities are presented in this volume of the SISMP. Where corrective actions are complete and RL has accepted closure of the vulnerability, the vulnerability is shown as complete and no additional discussions are provided. Program management is 1isted by vulnerability, and in the case of "retired facilities," by building.

Overall management of this SISMP and coordination and statusing of the actions is the responsibility of those listed below.

Overall completion of this program is tied to the completion of the DNFSB Recommendation 94-1 program and completion of turnover of retired facilities to the Environmental Restoration Program. Individual vulnerabilities will be closed out earlier as they are remediated.

RL Program Manager: D. W. Templeton 1-509-373-2966

Contractor Program Manager: T. E. Huber 1-509-373-1503

\subsection{SCOPE}

The scope of the Hanford's Plutonium Vulnerability Program is the remediation of the vulnerabilities shown in Table 1 . 
Table 1. Hanford Plutonium ES\&H Vulnerabilities

\begin{tabular}{|c|c|c|c|}
\hline NUMBER & TITLE & $\begin{array}{l}\text { DOE-HQ LIKELIHOOD \& } \\
\text { CONSEQUENCE }\end{array}$ & STATUS \\
\hline $\mathrm{RL}-1.0 .1$ & $\begin{array}{l}\text { Competing Priorities for } \\
\text { Experienced Personnel } \\
\text { (A11 Plutonium } \\
\text { Facilities) } \\
\end{array}$ & $N / A$ & Complete \\
\hline$R L-1 \cdot 0.2$ & $\begin{array}{l}\text { Penetration of Glovebox } \\
\text { Barriers (ATl Plutonium } \\
\text { Facilities) }\end{array}$ & High/Worker-Low & Complete \\
\hline $\mathrm{RL}-1 \cdot 0.3$ & $\begin{array}{l}\text { Isolation and Layaway of } \\
\text { Gloveboxes (All } \\
\text { Plutonium Facilities) }\end{array}$ & High/Worker-Low & Working \\
\hline $\mathrm{RL}-1.0 .4$ & $\begin{array}{l}\text { Polymer-Based Panels and } \\
\text { Glovebox Windows (All } \\
\text { Plutonium Facilities) }\end{array}$ & High/Worker-Low & Working \\
\hline $\mathrm{RL}-1.0 .5$ & $\begin{array}{l}\text { Penetration of } \\
\text { Contamination } \\
\text { Containment/Fixative } \\
\text { (All Plutonium } \\
\text { Facilities) } \\
\end{array}$ & High/Worker-Low & Working \\
\hline $\mathrm{RL}-2.0 .1$ & $\begin{array}{l}\text { Insufficient Knowledge } \\
\text { of Packaging } \\
\text { Configuration and Nature } \\
\text { of Material in Building } \\
324 \text { (PNL) }\end{array}$ & High/Worker-Low & Complete \\
\hline$R L-2.0 .2$ & $\begin{array}{l}\text { Insufficient Knowledge } \\
\text { of Packaging } \\
\text { Configuration and Nature } \\
\text { of Material in Building } \\
325 \text { (PNL) }\end{array}$ & High/Worker-Low & Working \\
\hline$R L-2 \cdot 0.3$ & $\begin{array}{l}\text { Insufficient Knowledge } \\
\text { of Packaging } \\
\text { Configuration and Nature } \\
\text { of Material in Other PNL } \\
\text { Buildings (PNL) }\end{array}$ & High/Worker-Low & Complete \\
\hline$R L-3.0 .1$ & $\begin{array}{l}\text { Criticality Accident } \\
\text { During Deactivation or } \\
\text { D\&D Activities Due to } \\
\text { Abnorma Conditions (A11 } \\
\text { WHC Plutonium } \\
\text { Facilities) }\end{array}$ & Medium/Worker-High & Working \\
\hline
\end{tabular}




\begin{tabular}{|c|c|c|c|}
\hline NUMBER & TITLE & $\begin{array}{l}\text { DOE-HQ LIKELIHOOD \& } \\
\text { CONSEQUENCE }\end{array}$ & STATUS \\
\hline$R L-3.1 .2 .1$ & $\begin{array}{l}232-Z \text { Incinerator } \\
\text { Contamination Release } \\
\text { Due to Seismic } \\
\text { Destruction of Building } \\
\text { (PFP) }\end{array}$ & $\begin{array}{l}\text { NPH* / Worker-High } \\
\text { Publ ic-Low } \\
\text { Environment-High }\end{array}$ & Complete \\
\hline $\mathrm{RL}-3.1 .2 .2$ & $\begin{array}{l}\text { Release of Plutonium } \\
\text { Holdup in Exhaust Ducts } \\
\text { Downstream of } 234-52 \\
\text { Final HEPA Filters Via } \\
291-Z \text { Stack Exhaust } \\
\text { Blowers (PFP) }\end{array}$ & $\begin{array}{l}\text { Low/Worker-Low } \\
\text { Environment-Medium }\end{array}$ & TBD \\
\hline $\mathrm{RL}-3.1 .2 .3$ & $\begin{array}{l}\text { Concrete Block Wal1 and } \\
\text { Doors at the South End } \\
\text { of the PRF Canyon Fail } \\
\text { DBE Analysis (PFP) }\end{array}$ & $\begin{array}{l}\text { NPH/Worker-High } \\
\text { Pubi ic-Low } \\
\text { Environment-High }\end{array}$ & Complete \\
\hline $\mathrm{RL}-3.1 .3 .1$ & $\begin{array}{l}\text { Hydrogen Generation in } \\
\text { Solution Storage } \\
\text { Containers Which Are Not } \\
\text { Vented (PFP) }\end{array}$ & High/Worker-High & Complete \\
\hline $\mathrm{RL}-3.1 .3 .2$ & $\begin{array}{l}\text { Plutonium Stored in } \\
\text { Unstable Forms (PFP) }\end{array}$ & High/Worker-High & $\begin{array}{l}\text { See SISMP } \\
\text { Vol } 1\end{array}$ \\
\hline $\mathrm{RL}-3.1 .3 \cdot 3$ & $\begin{array}{l}\text { Deterioration of Storage } \\
\text { Containers (PFP) }\end{array}$ & High/Worker-High & $\begin{array}{l}\text { See SISMP } \\
\text { Vol } 1\end{array}$ \\
\hline $\mathrm{RL}-3.1 .3 .4$ & $\begin{array}{l}\text { Insufficient Knowledge } \\
\text { of Packaging } \\
\text { Configuration and } \\
\text { Characterization of } \\
\text { Material (PFP) }\end{array}$ & High/Worker-High & $\begin{array}{l}\text { See SISMP } \\
\text { Vol } 1\end{array}$ \\
\hline $\mathrm{RL}-3.1 .4 .1$ & $\begin{array}{l}\text { Injury or Contamination } \\
\text { During PRF Canyon Entry } \\
\text { (PFP) }\end{array}$ & Low/Worker-High & Planning \\
\hline$R L-3.1 .4 .2$ & $\begin{array}{l}\text { Reactive Chemicals in } \\
\text { PFP Gloveboxes }\end{array}$ & High/Worker-Low & Complete \\
\hline $\mathrm{RL}-3.1 .5 .1$ & $\begin{array}{l}\text { Breach of Drain Lines } \\
\text { with Holdup in PFP }\end{array}$ & High/Worker-Low & Working \\
\hline$R L-3.1 .5 .2$ & $\begin{array}{l}\text { HF Corrosion of Exhaust } \\
\text { Ventilation Ductwork and } \\
\text { Primary Filters } \\
\text { Servicing Glovebox } H C-9 B \\
\text { and HA-46 in PFP }\end{array}$ & High/Worker-Low & Working \\
\hline
\end{tabular}




\begin{tabular}{|c|c|c|c|}
\hline NUMBER & TITLE & $\begin{array}{l}\text { DOE-HQ LIKELIHOOD \& } \\
\text { CONSEQUENCE }\end{array}$ & STATUS \\
\hline RL-3.1.5.3 & $\begin{array}{l}\text { Corrosion of Ductwork } \\
\text { Servicing Laboratories } \\
\text { by Acids (PFP) }\end{array}$ & Not Listed & Scoping \\
\hline RL-3.1.5.4 & $\begin{array}{l}\text { Worker Exposure from } \\
\text { Exhaust Ventilation } \\
\text { Ductwork and Process } \\
\text { Vacuum System (PFP) }\end{array}$ & High/Worker-Low & Working \\
\hline$R L-3.1 .6 .1$ & $\begin{array}{l}\text { Contamination and } \\
\text { Exposure from Cleaning } \\
242-Z \text { (PFP) }\end{array}$ & High/Worker-Low & TBD \\
\hline RL-3.2.1 & $\begin{array}{l}\text { PUREX Pu Residual } \\
\text { Inventory }\end{array}$ & High/Worker-Low & Working \\
\hline $\mathrm{RL}-3.2 .2$ & $\begin{array}{l}\text { Residuals in PUREX } \\
\text { Tunnels }\end{array}$ & $\begin{array}{l}\text { Low/ Worker-Low } \\
\text { Environment-Medium }\end{array}$ & TBD \\
\hline$R L-3.2 .3$ & $\begin{array}{l}\text { Release of Residual Deep } \\
\text { Bed Filter Contamination } \\
\text { Via the PUREX Main Stack }\end{array}$ & Low/ Worker-Low & TBD \\
\hline $\mathrm{RL}-3.2 .4$ & $\begin{array}{l}\text { Inadvertent Breach of } \\
\text { Gross Pu Contamination } \\
\text { Beneath Paint in the } \\
\text { PUREX White Room } \\
\end{array}$ & High/Worker-Medium & Working \\
\hline RL-3.3.1.1 & $\begin{array}{l}\text { Contamination Spread } \\
\text { Resulting from Loss of } \\
\text { Control Resulting from a } \\
\text { Roof Fire at Retired } \\
\text { Facilities }\end{array}$ & $\begin{array}{l}\text { Low/Worker-Medium } \\
\text { Publ ic-Medium } \\
\text { Environment-High }\end{array}$ & TBD \\
\hline $\mathrm{RL}-3.3 .1 .2$ & $\begin{array}{l}\text { Potential Loss of } \\
\text { Containment Integrity - } \\
\text { Retired Facilities: 222- } \\
\text { B \& T, 202-S, 308, 309, } \\
3706\end{array}$ & $\begin{array}{l}\text { Medium/Worker-Low } \\
\text { Environment-High }\end{array}$ & Working \\
\hline RL-3.3.2.1 & $\begin{array}{l}340 \text { Waste Handling } \\
\text { Complex Release to } \\
\text { Environment }\end{array}$ & Low/Worker-Low & TBD \\
\hline RL-3.3.2.2 & $\begin{array}{l}\text { Sand Filters at } 221-B \text {, } \\
221-T \text {, and } 202-S\end{array}$ & $\begin{array}{l}\text { Low/Worker-Low } \\
\text { Environment-Low }\end{array}$ & Complete \\
\hline RL-3.3.2.3 & $\begin{array}{l}\text { Z-9 Building Frequent } \\
\text { Contamination Outside of } \\
\text { Engineered Barriers }\end{array}$ & $\begin{array}{l}\text { High/Worker-Low } \\
\text { Environment-Medium }\end{array}$ & TBD \\
\hline$R L-3.3 .2 .4$ & $\begin{array}{l}\text { Release of Plutonium } \\
\text { from } 231-Z \text { Duct }\end{array}$ & $\begin{array}{l}\text { Low/No Target } \\
\text { specified }\end{array}$ & TBD \\
\hline
\end{tabular}


WHC-EP-0853 REV. 4

\begin{tabular}{||l|l|l|l||}
\hline NUMBER & TITLE & $\begin{array}{l}\text { DOE-HQ LIKELIHOOD \& } \\
\text { CONSEQUENCE }\end{array}$ & STATUS \\
\hline RL-3.3.2.5 & $\begin{array}{l}\text { Residual Plutonium in } \\
209-\mathrm{E}\end{array}$ & LOW/Worker-Low & TBD \\
\hline RL-WGAT-1 & $\begin{array}{l}\text { Criticality and } \\
\text { Contamination Potential } \\
\text { in Settling Tank 241-Z- } \\
361\end{array}$ & Low/Worker-High & TBD \\
\hline
\end{tabular}

* Natural Phenomena Hazards (NPH)

\subsection{RL-1.0.1 COMPETING PRIORITIES FOR EXPERIENCEO PERSONNEL}

Complete

\subsection{RL-1.0.2 PENETRATION OF GLOVEBOX BARRIERS}

Complete

\subsection{RL-1.0.3 ISOLATION AND LAYAWAY OF GLOVEBOXES}

RL Program Manager: D. W. Templeton 1-509-373-2966

Contractor Program Manager: T. E. Huber 1-509-373-1503

\subsection{Scope}

This vulnerability is applicable to the following facilities:

PFP BUILDINGS: $234-5 Z, 236-Z, 242-Z, 232-Z, 241-Z, 2736-Z B$

PUREX (202-A)

22I-B, 221-T, 216-Z-9, 209-E, 222-T, 231-Z, 308, 309, and 3706

\subsection{Remediation Objectives}

The objective of this remediation is to transition unneeded gloveboxes to a deactivated state that meets the criteria for turnover to the EM-40 program.

\subsection{Remediation Process}

Gloveboxes will be cleaned out to minimal holdup levels, excess equipment and combustibles removed, services (ie water, electrical, gas supply) terminated, residual contamination fixed in place, and all glovebox penetrations sealed.

\subsection{Schedule Objectives}

The schedule objectives for $\mathrm{RL}-1,0.3$ are shown in Table 2 . 
Table 2. Schedule objectives for RL-1.0.3

\begin{tabular}{||l|l|l|l|}
\hline BUILDING & START DATE & FINISH DATE & COMMENTS \\
\hline $234-5 Z$ & FY 1996 & FY 2003 & Working \\
\hline $236-Z$ & FY 1998 & FY 2000 & \\
\hline $242-Z$ & FY 1999 & FY 2003 & \\
\hline $232-Z$ & N/A & N/A & Complete \\
\hline $241-Z$ & FY 2001 & FY 2002 &. \\
\hline $2736-Z B$ & FY 1997 & FY 1997 & \\
\hline $202-A$ (PUREX) & FY 1994 & FY 1996 & \\
\hline $221-B$ & TBD & TBD & \\
\hline $221-T$ & TBD & TBD & \\
\hline $216-Z-9$ & FY 1999 & FY 2000 & \\
\hline $209-E$ & TBD & TBD & \\
\hline $222-T$ & TBD & TBD & \\
\hline $231-Z$ & FY 1999 & FY 2000 & \\
\hline 308 & N/A & N/A & Complete \\
\hline 309 & & FY 1998 & Working \\
\hline 3706 & TBD & TBD & \\
\hline
\end{tabular}

\subsection{Assumptions}

EM-40 acceptance criteria is unchanged from the January 1994 draft.

\subsection{Issues and Problems}

The EM-40 acceptance criteria is still in draft form.

\subsection{Alternatives/Impacts}

TBD

\subsection{Technology Development}

Fielding of technologies proven by DOE EM-50 will be sufficient for this work.

\subsection{RL-1.0.4 POLYMER-BASED PANELS AND GLOVEBOXES WINDOWS}

RL Program Manager: D. W. Templeton 1-509-373-2966

Contractor Program Manager: T. E. Huber 1-509-373-1503 


\subsection{Scope}

This vulnerability is applicable only to active plutonium processing facilities. Where these panels exist in inactive facilities, the vulnerability is a duplicate of $\mathrm{RL}-1 \cdot 0.3$. The buildings where this vulnerability is applicable are: 234-5Z, 236-Z, 241-Z. The 2736-ZB glovebox has glass windows.

\subsection{Remediation Objectives}

The objective of this remediation is to transition unneeded gloveboxes to a deactivated state that meets the criteria for turnover to the EM-40 program.

\subsection{Remediation Process}

Gloveboxes will be cleaned out to minimal holdup levels, excess equipment and combustibles removed, services (ie water, electrical, gas supply) terminated, residual contamination fixed in place, and all glovebox penetrations sealed.

\subsection{Schedule Objectives}

The schedule objectives for RL-1.0.4 are shown in Table 3 .

Table 3. Schedule Objectives for RL-1.0.4

\begin{tabular}{||l|l|l|l||}
\hline BUILDING & START DATE & FINISH DATE & COMMENTS \\
\hline $234-5 Z$ & FY 1996 & FY 2002 & \\
\hline $236-Z$ & FY 1998 & FY 2000 & \\
\hline $241-Z$ & FY 2001 & FY 2002 & \\
\hline
\end{tabular}

\subsection{Assumptions}

That the EM-40 acceptance criteria will be issued as drafted in the January 1994 draft.

\subsection{Issues and Problems}

The EM-40 acceptance criteria is still in draft form.

\subsection{Alternatives/Impacts}

N/A

\subsection{Technology Development}

$N / A$ 


\title{
6.0 RL-1.0.5 PENETRATION OF CONTAMINATION CONTAINMENT/FIXATIVE
}

\author{
RL Program Manager: D. W. Templeton 1-509-373-2966
}

Contractor Program Manager: T. E. Huber 1-509-373-1503

\subsection{Scope}

The typical method for containing contamination has been through the use of paint. The paint is applied after initial decontamination using methods such as washing and wiping. In most cases an initial coat of yellow paint was applied as a warning of contamination followed by a second coat of paint of a different color (often grey or white). No further markings were applied prior to about 1990. Since that time contamination areas are required to be labeled and mapped in addition to the painting described above.

This vulnerability is applicable to the following facilities:

234-5Z, 236-Z, 242-Z, 232-Z, 241-Z, 291-Z, 2736-Z, 2736-ZB, PUREX, 221-B, 221$T, 216-Z-9,209-E, 222-B, 222-T, 231-Z, 308,309$, and 3706 .

\subsection{Remediation Objectives}

The objective of this remediation is to remove all fixed contamination from areas where inadvertent containment penetration is likely. These areas include high traffic areas, areas exposed to the weather, areas subject to impact or abrasion. Where it is not feasible to remove contamination, the contamination will be marked, mapped, and controlled per the RadCon Manual requirements. In some areas new fixatives may be required.

For facilities in the process of deactivation, the end point for this remediation will be meeting the acceptance criteria for turnover to the EM-40 Program.

\subsection{Remediation Process}

The method for removal of fixed contamination will vary depending on the base strata. Contaminated asphalt is being cutout and disposed of as radioactive waste. Contaminated concrete can be scabbled or removed. Contaminated metal can be cleaned using any of a number of methods.

Where removal is not possible and where marking and mapping painted over contamination do not provide the needed level of protection to workers new fixative methods will be used. These include use of concrete caps or physical barriers.

\subsection{Schedule Objectives}

The schedule objectives for RL-1.0.5 are shown in Table 4 . 
Table 4. Schedule objectives for RL-1.0.5

\begin{tabular}{||l|l|l|l||}
\hline BUILDING & START DATE & COMPLETION DATE & STATUS \\
\hline $234-5 Z$ & MAY 1996 & FY 2003 & WORKING \\
\hline $236-Z$ & FY 1998 & FY 2000 & \\
\hline $242-Z$ & FY 1999 & FY 2003 & \\
\hline $232-Z$ & N/A & N/A & COMPLETE \\
\hline $241-Z$ & FY 2001 & FY 2002 & \\
\hline $291-Z$ & FY 1997 & FY 2003 & \\
\hline $2736-Z$ & FY 1997 & FY 1997 & \\
\hline $2736-Z B$ & FY 1997 & FY 1997 & \\
\hline PUREX & T992 & FY 1997 & WORKING \\
\hline $221-B$ & TBD & TBD & \\
\hline $221-T$ & TBD & TBD & \\
\hline $216-Z-9$ & FY 2001 & FY 2001 & \\
\hline $209-E$ & TBD & TBD & \\
\hline $222-B$ & N/A & N/A & COMPLETE \\
\hline $222-T$ & TBD & TBD & \\
\hline $231-Z$ & FY 1999 & FY 2000 & \\
\hline 308 & N/A & N/A & COMPLETE \\
\hline 309 & 1994 & FY 1998 & WORKING \\
\hline 3706 & TBD & TBD & \\
\hline
\end{tabular}

\subsection{Assumptions}

That compliance with the RadCon Manual requirements for decontaminating, containing, marking, and mapping contamination is sufficient for compliance with the EM-40 acceptance criteria.

\subsection{Issues and Problems}

The EM-40 acceptance criteria is still in draft form.

\subsection{Alternatives/Impacts}

N/A 


\title{
6.8 Technology Development
}

Decontamination technologies demonstrated by EM-50 will be sufficient for this scope of work.

\subsection{RL-2.0.1 INSUFFICIENT KNOWLEDGE OF PACKAGING CONFIGURATION AND NATURE OF MATERIAL IN BUILDING 324.}

Complete

\subsection{RL-2.0.2 INSUFFICIENT KNOWLEDGE OF PACKAGING CONFIGURATION AND NATURE OF MATERIAL IN BUILDING 325}

\author{
RL Program Manager: R. F. Christensen 1-509-372-4900 \\ Contractor Program Manager: D. M. Montgomery 1-509-376-4204
}

\subsection{Scope}

This vulnerability is applicable to Building 325

\subsection{Remediation objectives}

Surplus material will be shipped to PFP for stabilization in the DNFSB Recommendation 94-1 Program or disposed of as waste. Materials that will be maintained in use will be inspected and any resultant problems corrected.

\subsection{Remediation Process}

Excess usable plutonium-bearing material has been shipped to PFP and is currently stored in PFP's vaults. This material was inspected prior to shipping and does meet PFP's vault acceptance criteria. Excess material to be dispositioned as waste is being prepared for discard per Hanford solid waste acceptance criteria. Items to remain in service have been inspected and were found to be in acceptable condition.

\subsection{Schedule Objectives}

Work was initiated on this vulnerability in 1995. Completion of disposal of items declared as waste is scheduled for 1996

\subsection{Assumptions}

$N / A$

\subsection{Issues and Problems}

$N / A$

\subsection{Alternatives/Impacts}

N/A 
8.8 Technology Development

$N / A$

\subsection{RL-2.0.3 INSUFFICIENT KNOWLEDGE OF PACKAGING CONFIGURATION AND NATURE OF MATERIAL IN OTHER PNL BUILDINGS}

Complete

\subsection{RL-3.0.1 CRITICALITY ACCIDENT DURING DEACTIVATION OR D\&D ACTIVITIES DUE TO ABNORMAL CONDITIONS}

RL Program Manager: D. W. Templeton 1-509-373-2966

Contractor Program Manager: T. E. Huber 1-509-373-1503

\subsection{Scope}

This vulnerability is applicable to the following facilities: PFP, PUREX, 241Z-361 Tank, and 209E

\subsection{Remediation Objectives}

The objective of this remediation is to transition these facilities to a safe, deactivated state that meets the criteria for turnover to the EM-40 program. This includes the removal of excess fissile material and fixing residuals in place to preclude criticalities during future D\&D activities.

\subsection{Remediation Process}

The major parts of this remediation are the removal and disposition of excess fissile materials, fixing, marking, and mapping residual plutonium, and compliance with the criticality prevention program. Excess fissile material will be prepared for disposal to WIPP criteria or transferred to PFP for stabilization and storage.

\subsection{Schedule Objectives}

PFP Start: February 1996

Finish: September 2003

PUREX Complete

209-E TBD

241-Z-361 This issue is covered by vulnerability RL-WGAT-1.

\subsection{Assumptions}

None 


\subsection{Issues and Problems}

No programmatic guidance has been given to the 209E Building to initiate work associated with this vulnerability.

\subsection{Alternatives/Impacts}

N/A

\subsection{Technology Development}

$N / A$

11.0 RL-3.1.2.1 232-Z INCINERATOR CONTAMINATION RELEASE DUE TO SEISMIC DESTRUCTION OF BUILDING

Complete

\subsection{RL-3.1.2.2 RELEASE OF PLUTONIUM HOLDUP IN EXHAUST DUCTS DOWNSTREAM OF 234-5Z FINAL HEPA FILTERS VIA 291-Z STACK EXHAUST BLOWERS}

RL Program Manager: D. W. Templeton 1-509-373-2966 Contractor Program Manager: T. E. Huber 1-509-373-1503

\subsection{Scope}

This vulnerability is applicable to the 234-5Z and 291-Z Buildings. No assay data is available to positively quantify this vulnerability. Engineering estimates indicate up to 20 grams of plutonium is holdup in the ducts and plenum downstream of the 234-5Z final filters. Actual releases to the environment from this sources has been monitored for years. The releases are detectable, but are well below the regulatory limits.

\subsection{Remediation Objectives}

The objective of this remediation is eliminate the unfiltered airflow path by performing a modification to the ventilation system. This will be followed by cleaning out the ducts and plenum to meet the acceptance criteria for the EM40 program.

\subsection{Remediation Process}

The remediation of this vulnerability will start after the majority of the deactivation of the 234-5Z Building has occurred. Currently, it is envisioned that a new, but smaller, exhaust system complete with double HEPA filtration, a new stack, and air quality monitoring, will be constructed between the 23452 and 291-Z Buildings. This system will tie into the duct connecting these two buildings and will replace the current exhaust system. After tie-in of the new exhaust system, the 291-Z Stack will be capped. Air will then flow 
from all contamination areas through the filters. At this point cleanup can proceed without the risk of incidental releases to the environment.

\subsection{Schedule Objectives}

Start construction: FY 2002

Complete Cleanup: FY 2003

\subsection{Assumptions}

That sufficient funding will be available to perform the modifications.

\subsection{Issues and Problems}

The EM-40 acceptance criteria is still in draft form.

Complete holdup data is not available to enable quantification of the vulnerability.

\subsection{Alternatives/Impacts}

TBD

\subsection{Technology Development}

TBD

\subsection{RL-3.1.2.3 CONCRETE BLOCK WALL AND DOORS AT SOUTH END OF PRF CANYON FAIL DBE ANALYSIS}

Complete

\subsection{RL-3.1.3.1 HYDROGEN GENERATION IN SOLUTION STORAGE CONTAINERS WHICH ARE NOT VENTED}

Complete

\subsection{RL-3.1.3.2 PLUTONIUM STORED IN UNSTABLE FORMS}

RL Program Manager: D. W. Templeton 1-509-373-2966

Contractor Program Manager: T. E. Huber 1-509-373-1503

\subsection{Scope}

This vulnerability is applicable to selected plutonium-bearing residues, oxides, and metals stored in the 234-5Z and $2736-Z$ facilities.

The specific materials in question are:

Sludges

46 items of Incinerator Ash 
Sand, Slag, and Crucible

Polycubes

Metal turnings

\subsection{Remediation objectives}

The objective of this remediation is to transform these materials to a form suitable for 50 year storage or for discard to WIPP

T a specific dispositions for the materials in question are:

$\begin{array}{ll}\text { Sludges } & \text { Thermal stabilization } \\ 46 \text { items of Incinerator Ash } & \text { Thermal stabilization } \\ \text { Sand, Slag, and Crucible } & \text { Cementation and discard } \\ \text { Polycubes } & \text { Thermal stabilization } \\ \text { Metal turnings } & \text { Thermal stabilization }\end{array}$

\subsection{Remediation Process}

See SISMP Volume 1

\subsection{Schedule objectives}

See SISMP Volume 2

\subsection{Assumptions}

See SISMP Volume 1

15.6 Issues and Problems

See SISMP Volume 1

\subsection{Alternatives/Impacts}

N/A

\subsection{Technology Development}

N/A

\subsection{RL-3.1.3.3 DETERIORATION OF STORAGE CONTAINERS}

RL Program Manager: D. W. Templeton 1-509-373-2966

Contractor Program Manager: T. E. Huber 1-509-373-1503

\subsection{Scope}

This vulnerability is applicable to plutonium-bearing materials stored in Buildings $234-5 Z$ and $2736-z$ only. 


\subsection{Remediation Objectives}

The remediation of this vulnerability will be complete when either the container life assessment is complete with a finding that there are no imminent risks or that the inventory of plutonium-bearing materials is stabilized and packaged to DOE-STD-3013, the Interim Storage Criteria, or WIPP/WAC.

\subsection{Remediation Process}

See SISMP Volume 1 for the stabilization and repackaging portion of this remediation.

An evaluation of the condition of the storage containers used at PFP was initiated in March 1995. This evaluation includes visual inspections, radiography, and destructive evaluation of containers. To date no significant deterioration has been observed.

\subsection{Schedule Objectives}

See SISMP Volume 2 for the stabilization and packaging portion of this vulnerability.

Evaluation of the existing containers was started in March 1995 and will be completed in September 1998.

\subsection{Assumptions}

$N / A$

\subsection{Issues and Problems}

$N / A$

\subsection{Alternatives/Impacts}

N/A

\subsection{Technology Development}

N/A

\subsection{RL-3.1.3.4 INSUFFICIENT KNOWLEDGE OF PACKAGING CONFIGURATION AND CHARACTERIZATION OF MATERIAL}

RL Program Manager: D. W. Templeton 1-509-373-2966

Contractor Program Manager: T. E. Huber 1-509-373-1503

\subsection{Scope}

This vulnerability is applicable to selected plutonium-bearing items stored in the 234-5Z and 2736-Z Buildings. 


\subsection{Remediation Objectives}

Remediation of this vulnerability will be complete when the inventory of plutonium-bearing items is stabilized and packaged to meet the D0E-5T0-3013, the Criteria for Interim Storage of Plutonium Bearing Material, or WIPP/WAC, or the evaluation of the inventory has been completed and applicable characterization of the inventory has been obtained.

\subsection{Remediation Process}

See SISMP Volume 1 for stabilization and packaging information.

Characterization of the inventory will be done through review of available documentation, radiography, destructive and non-destructive evaluations.

\subsection{Schedule Objectives}

See SISMP Volume 2 for the stabilization and packaging information.

The evaluation of the packaging configuration of the storage containers used at PFP was initiated in March 1995. The evaluation is scheduled to be complete September 1998.

\subsection{Assumptions}

N/A

\subsection{Issues and Problems}

$$
\text { N/A }
$$

\subsection{Alternatives/Impacts}

$N / A$

\subsection{Technology Development}

N/A

\subsection{RL-3.1.4.1 INJURY OR CONTAMINATION DURING PRF CANYON ENTRY}

RL Program Manager: D. W. Templeton 1-509-373-2966

Contractor Program Manager: T. E. Huber 1-509-373-1503

\subsection{Scope}

This vulnerability is applicable to the $236-Z$ (PRF) Building only. The canyon is contaminated with plutonium that leaked out of the processing equipment during past production campaigns. The PRF facility is no longer in use but an estimated $12 \mathrm{kgs}$ of plutonium has been deposited on the canyon floor. 


\subsection{Remediation Objectives}

The objective of this remediation is to remove the plutonium contamination from the floor to a point that is acceptable to the EM-40 program. The method of removal has not been determined but is expected to be a remote.

\subsection{Remediation Process}

TBD

\subsection{Schedule Objectives}

This remediation is scheduled for FY 1999-2000

\subsection{Assumptions}

The EM-40 Acceptance Criteria in the Jan 1994 draft will be issued unchanged.

\subsection{Issues and Problems}

The EM-40 Acceptance Criteria is still in draft.

\subsection{Alternatives/Impacts}

TBD

\subsection{Technology Development}

TBD

\subsection{RL-3.1.4.2 REACTIVE CHEMICALS IN PFP GLOVEBOXES}

Complete

\subsection{RL-3.1.5.1 BREACH OF DRAIN LINES WITH HOLDUP IN PFP}

RL Program Manager: D. W. Templeton 1-509-373-2966

Contractor Program Manager: T. E. Huber 1-509-373-1503

\subsection{Scope}

This vulnerability is applicable to the exposed, abandoned, drain lines in the 234-5Z Building. The drain lines between the 234-5Z and 241-Z Buildings were replaced with double contained pipes. The active drain lines in 234-5Z were replaced with new lines in 1995 .

This vulnerability is also applicable to the 291-Z sump and associated drain lines. The sump is contains an estimated 20 grams of Pu. The Pu came from, now removed, process vacuum pumps. 


\subsection{Remediation Objectives}

Remediation of this vulnerability will be complete when the 291- $Z$ sump drain lines in the 234-5Z tunnels are cleaned to meet the EM-40 acceptance criteria. The drain lines in the 291-Z Building associated with the sump will be removed and replaced with new lines.

\subsection{Remediation Process}

Modifications to the area around the sump including the removal of old equipment is required prior to start of the cleanup. The flows into the sump will be routed to a catch tank outside the sump. When these modifications are complete the floor drains will be flushed and the sump will be pumped out. All other contaminated piping and pumps associated with the sump will be removed. The 291-Z sump will be cleaned out using standard industry methods. Following cleanup, any residual contamination will be quantified, fixed in place, marked and mapped per radiological control requirements.

\subsection{Schedule Objectives}

The remediation in $291-Z$ is ongoing and is scheduled for completion in $F Y$ 1997.

The remediation in $234-5 Z$ is scheduled for FY 2002.

\subsection{Assumptions}

The EM-40 Acceptance Criteria in the Jan 1994 draft will be issued unchanged.

\subsection{Issues and Problems}

The EM-40 Acceptance Criteria in still in draft form.

\subsection{Alternatives/Impacts}

$N / A$

\subsection{Technology Development}

$N / A$

\subsection{RL-3.1.5.2 HF CORROSION OF EXHAUST VENTILATION DUCTWORK AND PRIMARY FILTERS SERVICING GLOVEBOX HC-9B AND HA-46 IN PFP}

RL Program Manager: D. W. Templeton 1-509-373-2966

Contractor Program Manager: T. E. Huber 1-509-373-1503

\subsection{Scope}

This vulnerability is applicable to the 234-5Z Building only. Two portions of process exhaust duct are in question. They are the Filter Box 9A to 98 Bypass 
Duct and the ducting from Filter Boxes $9 A$ and $9 B$ to Filter Box $9 A B$. These ducts and filter boxes contain approximately $4 \mathrm{kgs}$ of plutonium.

\subsection{Remediation Objectives}

The objective of this remediation is to remove these segments of ducts since they are no longer required and they contain significant quantities of plutonium.

\subsection{Remediation Process}

The ducts will be segmented, moved to a glovebox where the loose plutonium is removed by brushing and collected for thermal stabilization. The duct is then crushed and packaged to WIPP/WAC in 55-gallon drums.

\subsection{Schedule Objectives}

Work Started February 1996 and will be completed by December 1996.

To date the Filter Box 9A to 9B Bypass Duct containing $2.1 \mathrm{kgs}$ of plutonium has been removed. The direct route to the 291-Z stack from Filter Box $9 A B$ has been removed and work is starting on the removal of the remaining duct work.

\subsection{Assumptions}

$N / A$

21.6 Issues and Problems

N/A

\subsection{Alternatives/Impacts}

$N / A$

\subsection{Technology Development}

$N / A$

\subsection{RL-3.1.5.3 CORROSION OF DUCTWORK SERVICING LABORATORIES BY ACIDS}

RL Program Manager: D. W. Templeton 1-509-373-2966

Contractor Program Manager: T. E. Huber 1-509-373-1503

\subsection{Scope}

This vulnerability is applicable to the ducting servicing the labs in the 234$5 Z$ Building. To date no specific ducts have been identified. 


\subsection{Remediation Objectives}

Evaluation of ducting removed during other duct remediation activities indicates that there may not be a real vulnerability. Additional visual inspections of potentially degraded ducts will occur during the rema:nder of FY 1996 and FY 1997.

\subsection{Remediation Process}

TBD. If degraded ducts are identified, they will be removed as described in section 4.21 .3 above.

\subsection{Schedule Objectives}

Scoping will be completed by the end of FY 1997. No specific issues have been identified to date so no specific remediation schedules can be developed.

\subsection{Assumptions}

N/A

\subsection{Issues and Problems}

$N / A$

\subsection{Alternatives/Impacts}

N/A

\subsection{Technology Development}

$N / A$

\subsection{RL-3.1.5.4 WORKER EXPOSURE FRON EXHAUST VENTILATION DUCTHORK AND PROCESS VACUUN SYSTEM}

RL Program Manager: D. W. Templeton 1-509-373-2966

Contractor Program Manager: T. E. Huber 1-509-373-1503

\subsection{Scope}

This vulnerability is applicable to the Process Vacuum System ducting both active and abandoned located in the 234-5Z and $291-Z$ Buildings, and the HF exhaust ducting located in Building 234-5Z (see Section 4.21 above)

\subsection{Remediation Objectives}

The objective of this remediation is to remove the ducting and filter boxes with significant plutonium holdup. 


\subsection{Remediation Process}

The ducts will be removed as described in section 21.0 above.

\subsection{Schedule objectives}

Remediation of the HF ducting started in FY 1996 and will be complete in FY 1997. Process Vacuum System remediation will occur in FY 1997.

\subsection{Assumptions}

N/A

23.6 Issues and Problems

N/A

\subsection{Alternatives/Impacts}

$N / A$

\subsection{Technology Development}

N/A

\subsection{RL-3.1.6.1 CONTAMINATION AND EXPOSURE FROM CLEANING 242-Z}

RL Program Manager: D. W. Templeton 1-509-373-2966

Contractor Program Manager: T. E. Huber 1-509-373-1503

\subsection{Scope}

This vulnerability is applicable to the 242-Z Building.

\subsection{Remediation Objectives}

The objective of this remediation is to transition the $242-2$ facility to the EM-40 Program.

\subsection{Remediation Process}

The method of decontamination has not been defined at this time.

\subsection{Schedule Objectives}

Start 242-Z Cleanup: FY 1999

Complete 242-Z deactivation and turnover: FY 2003

\subsection{Assumptions}

$$
\text { N/A }
$$




\subsection{Issues and Problems}

The EM-40 acceptance criteria for facility turnover has not been issued.

\subsection{Alternatives/Impacts}

TBD

\subsection{Technology Development}

TBD

\subsection{RL-3.2.1 PUREX PU RESIDUAL INVENTORY}

RL Program Manager: L. D. Romine 1-509-376-4747

Contractor Program Manager: D. G. Harlow 1-509-373-1095

\subsection{Scope}

This vulnerability is applicable to the 202-A Building only.

\subsection{Remediation Objectives}

The objective of this remediation is to clean out the residual inventory of plutonium in preparation for transition PUREX into the Environmental Restoration Program.

\subsection{Remediation Process}

The tanks and piping in the PUREX Canyon have been flushed and drained removing all possible residual inventory. Gloveboxes are being cleaned out to meet the acceptance criteria developed for the PUREX transition to EM-40. Following the cleaning, a contamination fixative will be applied to the glovebox to seal any residual contamination.

\subsection{Schedule Objectives}

PUREX cleanout of residual inventories to meet the EM-40 acceptance criteria is scheduled for the end of FY 1996.

\subsection{Assumptions}

$N / A$

\subsection{Issues and Problems}

N/A

\subsection{Alternatives/Impacts}

$N / A$ 


\subsection{Technology Development}

N/A

\subsection{RL-3.2.2 RESIDUALS IN PUREX TUNNELS}

RL Program Manager: L. D. Romine 1-509-376-4747

Contractor Program Manager: D. G. Harlow 1-509-373-1095

\subsection{Scope}

This vulnerability is applicable to the two PUREX Tunnels and the contaminated equipment stored in them.

\subsection{Remediation Objectives}

The tunnels will be transitioned to the Environmental restoration Program D\&D.

\subsection{Remediation Process}

All new storage in the tunnels has been stopped. The tunnels exhaust through the PUREX stack will be analyzed to verify no contamination spreads are occurring.

\subsection{Schedule Objectives}

Transition activities are scheduled to be complete by the end of FY 1996 .

\subsection{Assumptions}

$N / A$

\subsection{Issues and Problems}

No programmatic guidance has been issued for the PUREX tunnels disposition past deactivation.

\subsection{Alternatives/Impacts}

$N / A$

\subsection{Technology Development}

$N / A$

\subsection{RL-3.2.3 RELEASE OF RESIDUAL DEEP BED FILTER CONTAMINATION VIA THE PUREX MAIN STACK}

RL Program Manager: L. D. Romine 1-509-376-4747

Contractor Program Manager: D. G. Harlow 1-373-1095 


\subsection{Scope}

This vulnerability is applicable to the PUREX Stack.

\subsection{Remediation Objectives}

The deep bed filters will be transitioned to the Environmental Restoration Program for final D\&D.

\subsection{Remediation Process}

The deep bed filters will be posted per Radiological Control requirements. Filter \#1 will be isolated and Filter \#2 will remain in service to support the deactivated PUREX facility. All emissions from the stack are monitored to comply with air quality standards.

\subsection{Schedule Objectives}

PUREX deactivation is scheduled for FY 1997.

\subsection{Assumptions}

$N / A$

27.6 Issues and Problems

N/A

\subsection{Alternatives/Impacts}

N/A

\subsection{Technology Development}

N/A

\subsection{RL-3.2.4 INADVERTENT BREACH OF GROSS PU CONTAMINATION BENEATH PAINT IN THE PUREX WHITE ROON}

RL Program Manager: L. D. Romine 1-509-376-4747

Contractor Program Manager: D. G. Harlow 1-509-373-1095

\subsection{Scope}

This vulnerability is applicable to the 202-A Building.

\subsection{Remediation Objectives}

The objective of this remediation is to transition PUREX into the Environmental Restoration Program. 


\subsection{Remediation Process}

The White Room is currently being coated with a contamination fixative as part of the PUREX Deactivation Project.

\subsection{Schedule Objectives}

This work is scheduled to be finished by the end of FY 1996

\subsection{Assumptions}

N/A

\subsection{Issues and Problems}

$N / A$

\subsection{Alternatives/Impacts}

N/A

\subsection{Technology Development}

$N / A$

\subsection{RL-3.3.1.1 CONTAMINATION SPREAD RESULTING FROM LOSS OF CONTROL RESULTING FRON A ROOF FIRE AT RETIRED FACILITIES}

RL Program Manager: R. S. 011ero 1-509-376-0663

BLDG 209-E RL Program Manager: J. K. McClusky 1-509-372-0947

BLDG 209-E Contractor Program Manager: L. A. Garner 1-509-373-5617

BLDG 308 \& 309 RL Program Manager: 0. A. Farabee 1-509-376-8089

BLDG 308 \& 309 Contractor Program Manager: J. M. Steffen 1-509-376-0484

BLDG 3706 RL Program Manager: M.J. Elsen 1-509-376-8021

BLDG 3706 Contractor Program Manager: S. J. Mattair 1-509-373-0577

\subsection{Scope}

This vulnerability is applicable to the 209E, 308, 309, and 3706 Buildings.

\subsection{Remediation Objectives}

The objective of this remediation is to deactivate the vulnerable facilities and turn them over to the EM-40 Program for D\&D.

\subsection{Remediation Process}

The deactivation process will minimize facility hazards and reduce the consequence of contamination spread resulting from a roof fire. 


\subsection{Schedule Objectives}

The schedule objectives for RL-3.3.1.1 is shown in Table 5.

Table 5. Plutonium Vulnerability RL-3.3.1.1 Status

\begin{tabular}{||l|l|l|l||}
\hline $\begin{array}{l}\text { APPLICABLE } \\
\text { BUILDING }\end{array}$ & BUILDING STATUS & ROOF CONSTRUCTION & $\begin{array}{l}\text { VULNERABILITY } \\
\text { STATUS }\end{array}$ \\
\hline $209 E$ & $\begin{array}{l}\text { Active- waste } \\
\text { storage }\end{array}$ & $\begin{array}{l}\text { Wood with asphalt } \\
\text { shingles }\end{array}$ & $\begin{array}{l}\text { New composite } \\
\text { shingles reduce } \\
\text { vulnerability } \\
\text { Completion TBD. }\end{array}$ \\
\hline 308 & Deactivated & $\begin{array}{l}\text { Metal decking with } \\
\text { builtup membrane over } \\
\text { insulation board }\end{array}$ & Complete. \\
\hline 309 & Deactivating & $\begin{array}{l}\text { Metal decking with } \\
\text { builtup membrane over } \\
\text { insulation board }\end{array}$ & $\begin{array}{l}\text { Closure pending } \\
\text { formal turnover to } \\
\text { EM-40. } \\
\text { Completion FY-98 }\end{array}$ \\
\hline 3706 & offices vacant & $\begin{array}{l}\text { Wood with asphalt } \\
\text { shingles }\end{array}$ & Completion TBO \\
\hline
\end{tabular}

\subsection{Assumptions}

N/A

\subsection{Issues and Problems}

The acceptance criteria for the EM-40 Program has not been issued.

Funding has not been requested for the deactivation of the 3706 facility.

\subsection{Alternatives/Impacts}

$N / A$

29.8 Technology Development

$N / A$

30.0 RL-3.3.1.2 POTENTIAL LOSS OF CONTAINMENT INTEGRITY - RETIRED FACILITIES: 222-B \& T, 202-S, 308, 309, 3706

RL Program Manager: R. S. 011 ero 1-509-376-0663

BLDG 222-B COMPLETE

BLDG 202-S OUT-OF-SCOPE 
BLDG 222-T RL Program Manager: M. J. Elsen 1-509-376-8021

BLDG 222-T Contractor Program Manager: S. G. Mattair 1-509-373-0577

BLDG 308 \& 309 RL Program Manager: 0. A. Farabee 1-509-376-8089

BLDG 308 \& 309 Contractor Program Manager: J. M. Steffen 1-509-376-0484

BLDG 3706 RL Program Manager:M. J. Elsen 1-509-376-8021

BLDG 3706 Contractor Program Manager: S. G. Mattair 1-509-373-0577

\subsection{Scope}

This vulnerability is applicable to the 222-B, 222-T, 308, 309, 3706 Buildings only. 202-5 is specifically identified in the WGAT Report as out-of-scope for the Plutonium Vulnerability Program since it has been turned over to the Environmental Restoration Program.

\subsection{Remediation Objectives}

The objective of this remediation is to deactivate these facilities and turn them over to the EM-40 Program for D\&D.

\subsection{Remediation Process}

The deactivation process will minimize facility hazards and reduce the likelihood of a containment breach while waiting for D\&D.

\subsection{Schedule objectives}

The schedule objectives for $R L-3.3 .1 .2$ is shown in Table 6 .

Table 6. Plutonium Vulnerability RL-3.3.1.2 Status

\begin{tabular}{||l|l|l|l||}
\hline $\begin{array}{l}\text { APPLICABLE } \\
\text { BUILDING }\end{array}$ & BUILDING STATUS & DEACTIVATION DATE & $\begin{array}{l}\text { VULNERABILITY } \\
\text { STATUS }\end{array}$ \\
\hline \hline 222B & N/A & N/A & Complete \\
\hline $222 T$ & Shutdown & N/A & TBD, unfunded \\
\hline 308 & Deactivated & N/A & Complete \\
\hline 309 & Deactivating & 1998 & Working \\
\hline 3706 & Vacated & TBD & TBD, unfunded \\
\hline
\end{tabular}

\subsection{Assumptions}

TBD

\subsection{Issues and Problems}

The acceptance criteria for the EM-40 Program has not been issued. 
Programmatic guidance has not been issued and funding is not available for the deactivation of $222 \mathrm{~T}$ and 3706 facilities.

\subsection{Alternatives/Impacts}

TBD

\subsection{Technology Development}

TBD

\subsection{RL-3.3.2.1 340 WASTE HANDLING COMPLEX RELEASE \\ TO ENVIRONMENT}

RL Program Manager: T. K. Teynor 1-509-376-1366

Contractor Program Manager: L. W. Roberts 1-509-376-5657

\subsection{Scope}

This vulnerability is applicable to the 340-A Building tanks as they are the only structure that contains plutonium. The $340-A$ Building has six $8000-$ gallon above grade liquid storage tanks with approximately 33 grams of plutonium holdup.

\subsection{Remediation Objectives}

The objective of this remediation is to remove the plutonium-bearing sludge from the tanks and transport it to the Hanford Waste Tank Farms for disposal.

\subsection{Remediation Process}

The tanks will be flushed and the plutonium-bearing sludges will be loaded into rail tank cars for transport to the Hanford Tank Farms for disposal.

\subsection{Schedule Objectives}

The work is scheduled for fourth quarter FY 1997.

\subsection{Assumptions}

$N / A$

\subsection{Issues and Problems}

N/A

\subsection{Alternatives/Impacts}

$N / A$ 


\subsection{Technology Development}

N/A

32.0 RL-3.3.2.2 SAND FILTERS AT 221-B, 221-T, AND 202-S

Complete

\subsection{RL-3.3.2.3 Z-9 BUILDING FREQUENT CONTAMINATION OUTSIDE OF ENGINEERED BARRIERS}

RL Program Manager: D. W. Templeton 1-509-373-2966

Contractor Program Manager: T. E. Huber 1-509-373-1503

\subsection{Scope}

This vulnerability is applicable to the 216-Z-9 Building. This building was constructed over the $216-Z-9 \mathrm{crib}$ and was used to mine plutonium 1 aden soil out of the crib. More than $90 \mathrm{kgs}$ of plutonium were mined from the crib. This plutonium was packaged in waste drums and disposed of as TRU waste. The mining operations ceased in this building in the late 1970's but the facility was not deactivated or cleaned out to today's standards.

\subsection{Remediation Objectives}

The objective of this remediation is to deactivate the 216-2-9 Building and transition it to the EM-40 Program for D\&D.

\subsection{Remediation Process}

TBD

\subsection{Schedule Objectives}

Deactivation and cleanup is scheduled for FY 2001

\subsection{Assumptions}

$$
\text { N/A }
$$

\subsection{Issues and Problems}

The EM-40 acceptance criteria has not been issued.

\subsection{Alternatives/Impacts}

TBD

\subsection{Technology Development}

TBD 


\subsection{RL-3.3.2.4 RELEASE OF PLUTONIUM FROM 23I-Z DUCT}

RL Program Manager: D. W. Templeton 1-509-373-2966

Contractor Program Manager: TBD

\subsection{Scope}

This vulnerability is applicable to the $231-Z$ Building. No assay data is available on the 231-Z duct work.

\subsection{Remediation Objectives}

This vulnerability will be remediated when the plutonium holdup in the 231- $Z$ duct work is reduced to a state that is acceptable to the Environmental Restoration Program.

\subsection{Remediation Process}

TBD depending on the levels of plutonium holdup. It can be assumed that this remediation will be similar to that described in section 4.21 above. The remediation of the ducts can not start until the remaining gloveboxes are deactivated.

\subsection{Schedule objectives}

TBD

\subsection{Assumptions}

TBD

\subsection{Issues and Problems}

Programmatic ownership of this remediation is in question.

\subsection{Alternatives/Impacts}

TBD

\subsection{Technology Deveiopment}

$N / A$

\subsection{RL-3.3.2.5 RESIDUAL PLUTONIUM IN 209-E}

RL Program Manager: J. K. McClusky 1-509-372-0947

Contractor Program Manager: L. A. Garner 1-509-373-5617

\subsection{Scope}

This vulnerability is applicable to the 209-E Building only. 


\subsection{Remediation objectives}

The objective of this remediation is to transition 209-E to the Environmental Restoration Program.

\subsection{Remediation Process}

The restoration process has not been defined since no programmatic direction has been issued to perform the work.

\subsection{Schedule objectives}

TBD. Funding has been requested to initiate deactivation planning in FY 1997.

\subsection{Assumptions}

TBD

\subsection{Issues and Problems}

The acceptance criteria for the EM-40 Program has not been issued.

\subsection{Alternatives/Impacts}

TBD

\subsection{Technology Development}

TBD

\subsection{RL-WGAT-1 CRITICALITY AND CONTAMINATION POTENTIAL IN SETTLING TANK 241-Z-361}

RL Program Manager: D. W. Templeton 1-509-373-2966

Contractor Program Manager: T. E. Huber 1-509-373-1503

\subsection{Scope}

This vulnerability is applicable to the 241-Z-361 Tank only. This tank contains approximately 80,000 liters of plutonium-bearing sludge. Assays of the tank siudge indicate that between 30 and $75 \mathrm{kgs}$ of plutonium are contained in the sludge.

\subsection{Remediation Objectives}

Mitigation of this vulnerability will be complete when the sludge has been removed from the tank and packaged for WIPP disposal.

\subsection{Remediation Process}

The sludge will be removed from the tank using a method that ensures the plutonium concentrations in the sludge do not change. The sludge will be 
loaded into 55-gallon drums and prepared for WIPP disposal. Currently, the only preparation envisioned is to immobilize the sludge via cementation or equivalent.

After the sludge has been removed the tank will be prepared for turnover to the EM-40 program.

\subsection{Schedule objectives}

Start remediation: FY 2001

Finish remediation: FY 2003

\subsection{Assumptions}

That the concentration of the plutonium in the sludge will allow disposal without safeguards.

That immobilization of the sludge will be sufficient to meet the WIPP/WAC.

\subsection{Issues and Problems}

WIPP is not operational at this time. Hanford waste storage may be insufficient to support this work if WIPP does not open as scheduled in FY 1998.

\subsection{A1ternatives/Impacts}

TBD

\subsection{Technology Development}

TBD 
WHC-EP-0853 REV. 4

This page intentionally left blank 


\section{DISTRIBUTION}

Number of Copies

ONSITE

14 U.S. Department of Energy, Richland Operations office
R. A. Almquist
$\mathrm{N} 2-36$
R. M. Hiegel
S7 -41
0 . M. Holgado (5)
S7-41
E. D. Sellers
$57-41$
D. W. Templeton (5)
R3-79
Public Reading Room
$\mathrm{H} 2-53$

3 Pacific Northwest National Laboratory

J. H. Jarrett

P7-35

D. K. Kreid

$\mathrm{Kg}-18$

Hanford Technical Library

$\mathrm{PB}-55$

34 Westinghouse Hanford Company

G. B. Chronister T5-02

G. J. Cox (5) T5-50

J. C. Fulton R3-11

E. W. Gerber R3-86

W. J. Geuther T3-28

M. W. Gibson T5-55

K. R. Herzog (5) T5-50

T. E. Huber T5-50

R. K. Hulvey N2-33

S. L. Magnani R3-56

R. L. McCormack R3-86

A. N. Praga (10) R3-86

E. C. Vogt T5-50

J. C. Womack R3-86

SNF Project Files R3-11

Document Processing Center A3-94

Central Files A3-88

1 Duke Engineering \& Services Hanford, Inc.
R. W. Rasmussen
H5-30 
THIS PAGE INTENTIONALLY LEFT BLANK 